\title{
CEREAL CRISPBREAD IMPROVEMENT WITH DIETARY FIBRE FROM APPLE BY-PRODUCTS
}

\author{
Daiga Konrade, ${ }^{1}$ Dace Klava, ${ }^{2}$ Ilze Gramatina ${ }^{3}$
}

\begin{abstract}
In the production of apple juice, the by-products such as the peel, bark and seeds remain biologically active substances and a good source of dietary fibre. The aim of our study is to incorporate apple by-product flour (ABF) into cereal crispbreads and to determine the total dietary fibre (TDF) content, the colour and the structural changes after addition of ABF to cereal based extrudates. Hot air drying was applied for the preparation of $\mathrm{ABF}$ from apple pomace. For the development of new products, a laboratory single-screw extruder GÖTTFERT $1 \mathrm{~L}$ series (Germany) was used. An extrusion screw (compression ratio 2:1) at a speed of 60-80 rpm and a rectangular die (aperture: $20 \mathrm{~mm}$ wide, $1.0 \mathrm{~mm}$ high, $100 \mathrm{~mm}$ long) were also used. The basic ingredients for extruded crispbreads were wheat flour, rice flour, wheat bran, rye flour, oat flour with addition of $\mathrm{ABF}$ in different proportions $(5 \%, 10 \%, 15 \%)$. The content of total dietary fibre (TDF) was determined according to the AOAC -AACC method No.985.29 by FOSS Analytical Fibertec E 1023 system. Density, textural properties

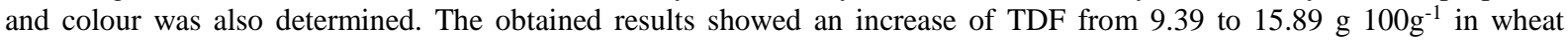

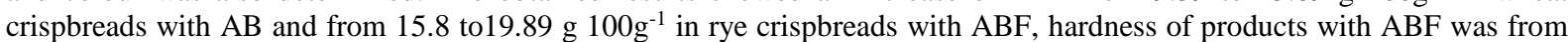
$17.2-21.7 \mathrm{~N}$ and density from $0.24-0.35 \mathrm{~g} \mathrm{~cm}^{-3}$, moisture of final product was $3.89-4.24 \pm 0.01 \%$. The main purpose of the current research was to determine the effect of $\mathrm{ABF}$ addition to cereal crispbread content, of the TDF and the textural properties.
\end{abstract}

UDC Classification: 664.6/.7; DOI: http://dx.doi.org/10.12955/cbup.v5.1085

Keywords: apple by- products, crispbreads, extrusion, dietary fibre

\section{Introduction}

Apple processing in the food industry results in a significant number of by-products such as the peel, mark, bark, and seeds which are still rich in bioactive compounds promoting health benefits. The high amount of dietary fibre could permit the use of them in developing new natural ingredients for the food industry (Figuerola \& Mar, 2005). Apple wastes are good sources of fibre with a well-balanced proportion between soluble and insoluble fraction (Eskicioglu et al., 2015). The apple pomace have

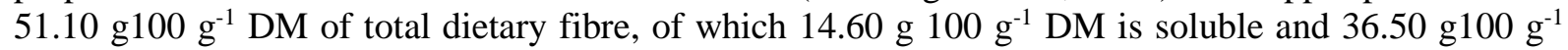
DM is insoluble dietary fibre (Olfe et al., 2003). Comparable to whole grain oat that contains the highest amounts of soluble fibre (6-8 g/100 g) among all cereal grains (Rodehutscord et al., 2016).

The apple peel may be used in the formulation of functional foods and beverages (Henr1, Almonacid, Lutz, Simpson, \& Valdenegro, 2013).

Extruded crispbreads are produced from cereals: rye, wheat, rice, maize, based on high starch content (Kaur et al., 2015, Guine et al., 2013). Grains are important energy sources providing much of the carbohydrates, some proteins, lipids, dietary fibre, and other micronutrients in many diets. Fruits, oats whole grain cereals, bran and rye are good source of dietary fibre $\beta$ - glycan, cellulose, hemicellulose and lignin (Dreher, 2001).

Dietary fibre (DF) includes a mixture of plant carbohydrate polymers, both oligosaccharides and polysaccharides, e.g., cellulose, hemicelluloses, pectin substances, gums, resistant starch, inulin, that may be associated with lignin and other non-carbohydrate components (e.g., polyphenols, waxes, saponins, cutin, phytates, resistant protein) (Elleuch et al., 2011). High DF diets prevent some diseases, such as diverticular and coronary heart diseases (Figuerola \& Mar, 2005). DF improves serum lipid concentrations, , improves blood glucose control in diabetes, lowers blood pressure and appears to improve immune function (Yde et al., 2011). Dietary fibre intake should range from 20 to 35 grams per day or 10-13 g per $1000 \mathrm{kcal}$ (Kohajdová et al., 2011).

The purpose of the study is to incorporate apple by-products in cereal based extrudates to obtain product with higher total dietary fibre content and to determine how chemical composition of ABF and TDF influence the physical properties of the final product.

\footnotetext{
${ }^{1}$ Latvia University of Agriculture,Faculty of Food Technology, daigakonrade@ gmail.com

${ }^{2}$ Latvia University of Agriculture, Faculty of Food Technology, dace.klava@llu.lv

${ }^{3}$ Latvia University of Agriculture, Faculty of Food Technology, ilzegramatina@inbox.lv
} 


\section{Materials and methods}

The study was realized at the scientific laboratories of the Faculty of Food Technology at the Latvia University of Agriculture.

For development of crispbreads we used wheat flour, rice flour obtained from rice grains by grinding, 2365 type wheat bran, rye flour and oat flour, water.

Experimental samples were prepared with addition of apple by-product powder 5\%, 10\%, and $15 \%$ to dry ingredients.

\begin{tabular}{|l|r|r|r|r|r|r|}
\hline Table 1: Composition of apple by-product flour and soft ingredients \\
\hline & $\begin{array}{r}\text { Sample } \\
\text { Moisture } \\
(\boldsymbol{\%})\end{array}$ & Pectins & Carbohydrates, \% & Protein,\% & Fat, \% & DF, \% \\
\hline Rye & 12.8 & & $53.3 \pm 0.28$ & $10.44-11.02$ & 1.9 & \\
\hline Oats & 12.1 & & 72 & 12.4 & 8.2 & \\
\hline Wheat & 13,9 & & 72 & 13,7 & 1,9 & 12,2 \\
\hline Rice & 12,8 & & 81 & 6,7 & 2,8 & 2,8 \\
\hline Wheat bran & 4.0 & & 64 & 15,5 & 4,3 & 4,2 \\
\hline $\begin{array}{l}\text { Apple by } \\
\text { product } \\
\text { powder }\end{array}$ & 5,36 & $20,42^{*}$ & $55,4($ sugar) & $2.3 \pm 0.2^{* *}$ & $2,1^{* *}$ & 42,7 \\
\hline Source: Author & & & & & & \\
\hline
\end{tabular}

Crispbreads were prepared with recipes attached in Table 2. All samples were based on $85-95 \%$ of cereals.

\begin{tabular}{|c|c|c|c|c|c|c|c|c|}
\hline \multicolumn{9}{|c|}{ Table2: Composition of samples } \\
\hline $\begin{array}{l}\text { Ingredient, } g \\
100 \mathrm{~g}^{-1}\end{array}$ & S1 & S2 & S11 & S12 & $\mathbf{S 1 3}$ & $\mathbf{S 2 1}$ & $\mathbf{S 2 2}$ & $\mathbf{S 2 3}$ \\
\hline Rye flour & & 80 & & & & 77.5 & 75.0 & 72.5 \\
\hline Oat flour & & 20 & & & & 17.5 & 15.0 & 12.5 \\
\hline Rice flour & 24 & & 22.8 & 21.6 & 20.4 & & & \\
\hline Wheat flour & 70 & & 66.5 & 63 & 59.5 & & & \\
\hline Wheat bran & 4 & & 3,8 & 3,6 & 3,4 & & & \\
\hline Apple BPF & & & 5.0 & 10.0 & 15.0 & 5.0 & 10.0 & 15.0 \\
\hline
\end{tabular}

Extrusion was done with a laboratory single-screw extruder GÖTTFERT 1 screw Extrusiometer L series (Germany). An extrusion screw (compression ratio 2:1) at a speed of 60-80 rpm and a rectangular die (aperture: $20 \mathrm{~mm}$ wide, $1.0 \mathrm{~mm}$ high, $100 \mathrm{~mm}$ long) were used. Temperatures for the extrusion process were set $78 \pm 2^{\circ} \mathrm{C} / 83 \pm 2^{\circ} \mathrm{C} / 98 \pm 2^{\circ} \mathrm{C}$.

The moisture content of the selected material was determined by standard method with Memmert equipment Modell-100-800 according to standard LVS EN ISO712:2010 A.

Water activity (aw) was determined according to ISO 21807: 2004.

The total content of dietary fibre (TDF) was determined according to the AOAC -AACC method No.985.29 -1986 by FOSS Analytical Fibertec E 1023 system.

Textural properties of extruded cereal- apple by-products were measured using a TA HD texture analyzer Stable Micro Systems. The test was performed by compressing the samples to $80 \%$ of their original diameter using a 35-mm compression plate at test speed of $2 \mathrm{~mm} \mathrm{~s}^{-1}$. Peak force $(\mathrm{N})$, number of peaks, and initial gradient $\left(\mathrm{N} \mathrm{mm}^{-1}\right)$ of the force-deformation curve was recorded and used to calculate hardness, crispiness of the products. An average of 10 samples was used to determine these properties. 
Piece density of extrudates was determined by using a sand displacement method. Piece density was defined as the ratio of the sample mass of the sample to its volume to include internal pores but exclude the void or space between the extrudates and was measured by filling a container of known volume with the product. The procedure was repeated five times for each set of samples.

Colour changes of product samples in the colour system CIE L*a*b* were determined by means of the Colour Tec-PCMTM equipment according to ISO 11664-4: 2011

Results were expressed in SIE $\mathrm{L}^{*} \mathrm{a} \mathrm{b}^{*}$ system as tri-stimulus values (L* lightness, $\mathrm{a}^{*}$ greenness/redness, $b^{*}$ blueness and yellowness. Measures for each sample were done in 10 replications. Total color difference $(\Delta \mathrm{E})$ was determined using the equation described by Garau et al. (2007).

The analysis of the experimental data was done in accordance with mathematical statistical methods used MS Excel 2007 software.

\section{Results and Discussion}

\section{Determination of TDF and textural properties of samples}

Textural and functional properties are the main decisive factor for acceptability of a snack food in the market. The incorporation of fibre in the extruded crispbreads generally results in changes of the nutrient profile (moisture and water activity) and physical properties (structure and texture) of the final extruded products (Brennan et al., 2008a). Thermal and mechanical treatment can reduce total dietary fibre (TDF). By incorporating 5 to $15 \% \mathrm{ABF}$, the TDF content of extruded products increased from

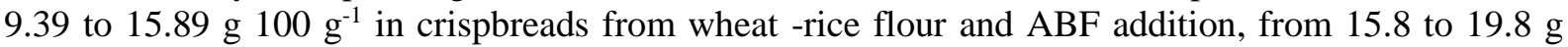
$100 \mathrm{~g}^{-1}$ in rye crispbreads with $\mathrm{ABF}$.

\begin{tabular}{|l|l|r|r|r|r|}
\hline Table 3: TDF, piece density and moisture content \\
\hline & $\begin{array}{r}\text { TDF, } \\
\mathbf{1 0 0 g}^{-1}\end{array}$ & $\begin{array}{r}\text { Moisture of } \\
\text { samples, \%, }\end{array}$ & $\begin{array}{r}\text { Piece } \\
\text { density* }\end{array}$ & $\begin{array}{r}\text { Water } \\
\text { activity }\end{array}$ \\
\cline { 2 - 6 } & S1 & $9.39 \pm 0.37$ & $4.24 \pm 0.02$ & $0.15 \pm 0.02$ & $0.42 \pm 0.01$ \\
\cline { 2 - 6 } & S2 & $15.8 \pm 1.57$ & $4.22 \pm 0.03$ & $0.16 \pm 0.02$ & $0.41 \pm 0.01$ \\
\cline { 2 - 6 } & $\mathbf{S 1 . 1}$ & $10.6 \pm 0.59$ & $4.25 \pm 0.02$ & $0.12 \pm 0.03$ & $0.45 \pm 0.01$ \\
\cline { 2 - 6 } & $\mathbf{S 1 . 2}$ & $12.86 \pm 0.46$ & $4.01 \pm 0.10$ & $0.13 \pm 0.04$ & $0.46 \pm 0.01$ \\
\cline { 2 - 6 } & $\mathbf{S 1 . 3}$ & $15.89 \pm 0.96$ & $4.12 \pm 0.09$ & $0.17 \pm 0.02$ & $0.49 \pm 0.01$ \\
\cline { 2 - 6 } & $\mathbf{S 2 . 1}$ & $16.21 \pm 0.52$ & $4.11 \pm 0.02$ & $0.14 \pm 0.03$ & $0.36 \pm 0.01$ \\
\cline { 2 - 6 } & $\mathbf{S 2 . 2}$ & $18.22 \pm 0.56$ & $3.87 \pm 0.04$ & $0.16 \pm 0.02$ & $0.36 \pm 0.01$ \\
\cline { 2 - 6 } & $\mathbf{S 2 . 3}$ & $19.89 \pm 1.02$ & $3.89 \pm 0.01$ & $0.18 \pm 0.04$ & $0.39 \pm 0.01$ \\
\hline Source: Author
\end{tabular}

Fibre is usually used as a bulking agent, to provide nutritional attributes and to modify the texture of extruded products. Fruit fibre has better quality due to higher total and soluble fibre content, water and oil holding capacity and colonic fermentability, as well as lower caloric value (Figuerola \& Mar, 2005, Dreher, 2001). The purity of the fibres has a direct influence on the expansion characteristics. Fibre usage is often limited by its effect on product expansion. The addition of oat and rice fibre normally reduces expansion characteristics (Huber, 2001). Fibre, cellulose, bran and fruit-derived pectin may be blended with cereal grain or protein blends to make healthful snacks. Fibre and proteins may each be added at $20 \%$ levels to expanded snack formulations. Higher levels can be added when more soluble fibres and proteins are used. Low levels of low-molecular weight starches also counter the effects of fibre and protein additions. Extrusion-reacted fibre or bran yields softer-textured snacks when high levels of fibre are desired (Huber, 2001). Apples are rich in components that influenced the extrusion process and final product.

The textural characteristics of samples with ABF are given in Figure 1 and Table 3. The toughness of the extruded products is highly dependent on its moisture and density. Starch structure is distorted at high temperatures leading to a harder product. $\mathrm{ABF}$ extrudates were crisper compared to cereal based extrudates that is a harder product. The 5-15\% ABF incorporated products showed light in weight with piece density ranging from 0.15 to $0.17 \mathrm{~g} \mathrm{~cm}^{-3}$. Correlation between TDF and ABF addition is $\mathrm{r}=0.71$. 
Typical commercial low-density puffed snacks prepared by conventional steam extrusion have a density in the range of $0.02-0.7 \mathrm{~g} \mathrm{~cm}^{-3}$ and the ABF-based extrudates fall well within this range, indicating the potential of incorporating of $\mathrm{ABF}$ into crispbreads without impairing their textural qualities. Compared to cereal-alone extrudates, in $\mathrm{ABF}$ incorporated extrudates, bulk density increased from 0.15 to $0.17 \mathrm{~g} \mathrm{~cm}^{-3}$.

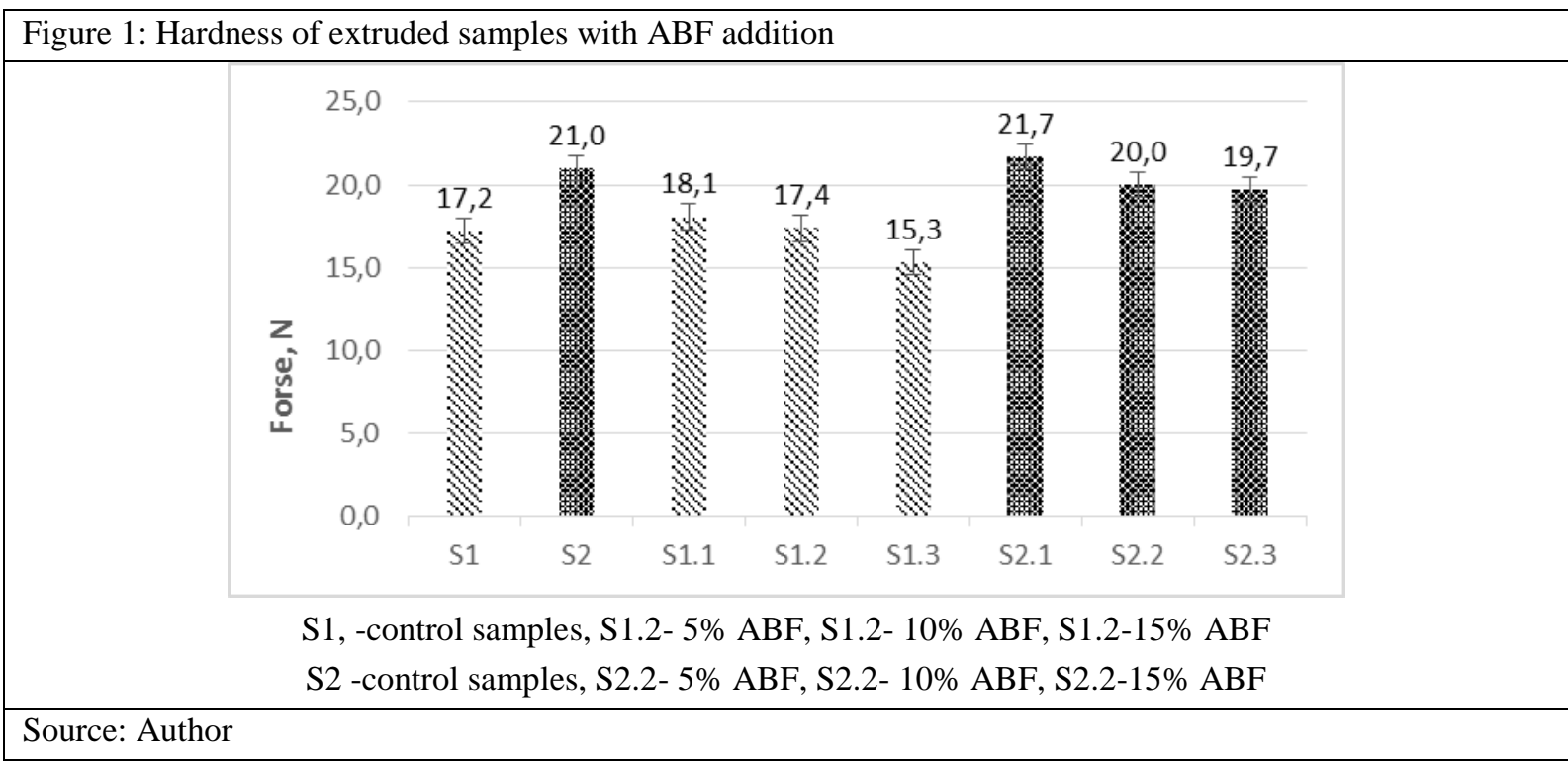

As apples contain sugar, they can alter the taste and texture of products, but the resulting material may also be very sticky. Apple pomace incorporation affected the hardness and crispiness of the products. Protein, fibre, fat and sugar present in them acts as diluents (Henr et al., 2010). This contradicted the typical inverse relationship between TDF and hardness; an increase in TDF generally decreases the hardness of extrudate though the addition of ABF increased hardness in comparison with both control samples. For control, sample S1 hardness was $17.2 \pm 0,8 \mathrm{~N}$ and the addition of $5 \%$ of ABF increased hardness to $18.1 \mathrm{~N}$, more addition decreased hardness to $15.3 \mathrm{~N}$. T. The most light and crispy products were with the addition of $15 \%$ ABF. The correlation between TDF and hardness of extrudates is $r=0.47$, and $r=0.04$ between density and hardness of extruded samples. Some authors reported that the addition of pomace or fibre reduced radial expansion of starch- based extrudates. The pulp that is added to the flour mix has soluble sugars and fibres that absorb moisture which further influenced the density, Hsieh et al. (1989) has also suggested that presence of insoluble fibre reduces the elasticity and plasticity of dough. However, there is still a dearth of information and knowledge on how the different ingredients (for instance sugars and dietary fibres) affect the rheological properties of the extrudates (Altan et al., 2008, O’Shea et al., 2012).

\section{Colour}

Colour is an important quality factor related to consumer acceptability.

The addition of reducing sugars can have a detrimental effect on available lysine and browning can occur (Bhattacharya, 1981). The addition of ABF did not cause significant colour change, indicating the absence of the browning reaction in final extrudates even though the feed formulation of pomace contained a considerable amount of soluble sugars.

Colour changes were analyzed for samples with $\mathrm{ABF}$ addition.

Total colour difference $\Delta \mathrm{E}^{*}=\left(\left(\mathrm{L}_{0} *-\mathrm{L}^{*}\right)^{2}+\left(\mathrm{a}_{0} *-\mathrm{a}^{*}\right)^{2}+\left(\mathrm{b}_{0} *-\mathrm{b}^{*}\right)^{2}\right)^{1 / 2}$

The results showed significant differences between all samples with $\mathrm{ABF}$ addition and control samples (3.64< $\left.\Delta \mathrm{E}^{*}<4.94\right)$. The differences between samples of ABF from $5 \%$ to $15 \%$ were not significant $\left(\Delta \mathrm{E}^{*}=0.82,0.85,0.66\right.$ and 0.73$)$. 


\begin{tabular}{|l|l|r|r|r|r|r|}
\hline \multicolumn{6}{|c|}{ Table 4: Colour difference of product samples in the color system CIE L*a*b* } \\
\hline & & $\mathbf{L}^{*}$ & $\mathbf{a}^{*}$ & $\mathbf{b}^{*}$ & $\boldsymbol{\Delta} \mathbf{E}^{*}$ & $\Delta \mathbf{E}^{*} \mathbf{1}$ \\
\cline { 2 - 7 } & $\mathbf{S 1}$ & 55.77 & 1.92 & 23.97 & 0.00 & \\
\cline { 2 - 7 } & $\mathbf{S 2}$ & 58.45 & 0.10 & 16.50 & 0.00 & \\
\cline { 2 - 7 } & $\mathbf{S 1 . 1}$ & 56.09 & 2.05 & 20.38 & 3.61 & 0.00 \\
\cline { 2 - 7 } & $\mathbf{S 1 . 2}$ & 56.84 & 2.36 & 20.55 & 4.91 & 0.83 \\
\cline { 2 - 7 } & $\mathbf{S 1 . 3}$ & 57.04 & 2.44 & 21.38 & 1.43 & 0.86 \\
\cline { 2 - 7 } & $\mathbf{S 2 . 1}$ & 59.45 & 0.28 & 19.71 & 3.37 & 0.00 \\
\cline { 2 - 7 } & $\mathbf{S 2 . 2}$ & 60.09 & 0.33 & 19.88 & 4.38 & 0.66 \\
\cline { 2 - 7 } & $\mathbf{S 2 . 3}$ & 60.77 & 0.59 & 20.01 & 4.34 & 0.74 \\
\hline Source: Author & & & & \\
\hline
\end{tabular}

Extrusion of $\mathrm{ABF}$ additionally decreased the lightness of samples, colour saturation ( $\left.\mathrm{L}^{*}\right)$ and hue did not show a clear trend. Some authors also reported a darkened colour of the extrudates due to Maillard browning during extrusion which also can cause the colour change (Devi et al., 2013, Nayak et al., 2011, Jain et al., 2013).

\section{Conclusion}

Results show that ABF from apple processing could be considered as an alternative dietary fibre in extruded cereal products. Utilization of apple pomace offers opportunity to produce extruded foods with functional properties. Apple by-products can increase the level of TDF of the new product. Extrusion is possible with 1 screw extruder at the temperature $78 / 83 / 98^{\circ} \mathrm{C}$.

\section{Acknowledgments}

Research has been supported by the National research program "Agricultural Resources for Sustainable Production of Qualitative and Healthy Foods in Latvia" (AgroBioRes) (2014- 2017), project No. 4 "Sustainable use of local agricultural resources for qualitative and healthy food product development" (FOOD).

\section{References}

Altan, A., Mccarthy, K. L., \& Maskan, M. (2008). Evaluation of snack foods from barley - tomato pomace blends by extrusion processing, 84, 231-242. http://doi.org/10.1016/j.jfoodeng.2007.05.014

Bhattacharya, S. (n.d.). Materials for 3 Raw Extrusion of Foods, 69-86.

Devi, N. L., Shobha, S., Tang, X., Shaur, S. A., Dogan, H., Alavi, S., \& Al, D. E. T. (2013). DEVELOPMENT OF

PROTEIN-RICH SORGHUM-BASED EXPANDED SNACKS USING EXTRUSION TECHNOLOGY, (July 2010), 263-

276. http://doi.org/10.1080/10942912.2011.551865

Dreher, M. L. (2001). Dietary fiber Overview. Handbook of Dietary Fiber, 14(12), 1-16. Retrieved from http://www.ncbi.nlm.nih.gov/pubmed/10089109

Elleuch, M., Bedigian, D., Roiseux, O., Besbes, S., Blecker, C., \& Attia, H. (2011). Dietary fibre and fibre-rich by-products of food processing: Characterisation, technological functionality and commercial applications: A review. Food Chemistry, 124(2), 411-421. http://doi.org/10.1016/j.foodchem.2010.06.077

Eskicioglu, V., Kamiloglu, S., \& Nilufer-erdil, D. (2015). Antioxidant Dietary Fibres : Potential Functional Food Ingredients from Plant Processing By-Products, 2015(6), 487-499. http://doi.org/10.17221/42/2015-CJFS

Figuerola, F., \& Mar, A. (2005). Food Chemistry Fibre concentrates from apple pomace and citrus peel as potential fibre sources for food enrichment, 91, 395-401. http://doi.org/10.1016/j.foodchem.2004.04.036

Guine, Raquel de Pinho Ferreira Correia, P. M. dos R. (2013). Engineering Aspects of Cereal and Cereal-Based Products, 367. Retrieved from https://books.google.com/books?id=3RHSBQAAQBAJ\&pgis=1

Henr, C., Chiffelle, I., Valenzuela, T., Araya, M., Simpson, R., \& Almonacid, S. (2010). Development of an Ingredient Containing Apple Peel , as a Source of Polyphenols and Dietary Fiber, 75(6). http://doi.org/10.1111/j.17503841.2010.01700.x

Henrı, M., Almonacid, S., Lutz, M., Simpson, R., \& Valdenegro, M. (2013). Comparison of three drying processes to obtain an apple peel food ingredient ' $\mathrm{n}$ de tres procesos de secado para obtener un ingrediente alimentario de ca 'scara de Comparacio manzana, 11(2), 127-135.

Huber, G. (2001). Snack Foods from Cooking Extruders. Snack Foods Processing. http://doi.org/doi:10.1201/9781420012545.ch12

Jain, D., Devi, M., \& Thakur, N. (2013). Study on the effect of machine operative parameters on physical characteristics of rice/maize based fruit/vegetable pulp fortified extrudates. Agricultural Engineering International: CIGR Journal, 15(2), 231- 
242.

Kaur, G. J., Rehal, J., Singh, B., Singh, A. K., \& Kaur, A. (2015). Development of multigrain breakfast cereal using extrusion technology. Asian Journal of Dairy and Food Research, 34(3), 219. http://doi.org/10.5958/0976-0563.2015.00043.3

Kohajdová, Z., Karovi, J., Jurasová, M., \& Kukurová, K. (2011). Effect of the addition of commercial apple fibre powder on the baking and sensory properties of cookies, 4(2), 88-97.

Nayak, B., Berrios, J. D. J., Powers, J. R., \& Tang, J. (2011). Effect of Extrusion on the Antioxidant Capacity and Color Attributes of Expanded Extrudates Prepared from Purple Potato and Yellow Pea Flour Mixes, 76(6), 874-884. http://doi.org/10.1111/j.1750-3841.2011.02279.x

O'Shea, N., Arendt, E. K., \& Gallagher, E. (2012). Dietary fibre and phytochemical characteristics of fruit and vegetable byproducts and their recent applications as novel ingredients in food products. Innovative Food Science and Emerging Technologies, 16, 1-10. http://doi.org/10.1016/j.ifset.2012.06.002

Olfe, K. E. W., Ianzhong, X. W. U., \& Iu, R. U. I. H. A. I. L. (2003). Antioxidant Activity of Apple Peels, 609-614.

Rodehutscord, M., Rückert, C., Maurer, H. P., Schenkel, H., Schipprack, W., Bach Knudsen, K. E., ... Mosenthin, R. (2016). Variation in chemical composition and physical characteristics of cereal grains from different genotypes. Archives of Animal Nutrition, 70(2), 87-107. http://doi.org/10.1080/1745039X.2015.1133111

Yde, C. C., Bertram, H. C., Theil, P. K., \& Knudsen, K. E. B. (2011). Effects of high dietary fibre diets formulated from byproducts from vegetable and agricultural industries on plasma metabolites in gestating sows. Archives of Animal Nutrition, 65(6), 460-476. http://doi.org/10.1080/1745039X.2011.621284 